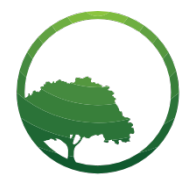

Research in Business \& Social Science

IJRBS VOL 8 NO 5 ISSN: 2147-4478

\title{
Influence of supportive and participative path-goal leadership styles and the moderating role of task structure on employee performance
}

\author{
Rozmina Rana ${ }^{a *}$, George K'aol ${ }^{b}$, Michael Kirubi ${ }^{c}$ \\ ${ }^{a, b, c}$ Chandaria School of Business, United States International University, P.O. Box 14634 - 00800, Nairobi, Kenya
}

Crossref

\begin{tabular}{l} 
A R T I C L E IN F O \\
\hline Article history: \\
Received 16 July 19 \\
Received in revised form 31 July 19 \\
Accepted 04 August 19 \\
\hline Keywords: \\
Path-Goal Theory \\
Leadership styles \\
Supportive \\
Participative \\
Task Structure \\
Employee Job Performance \\
JEL Classification: \\
O15 \\
P36 \\
\hline
\end{tabular}

\begin{abstract}
A B S T R A C T
This study examined the influence of supportive and participative path-goal leadership styles, and the moderating role of task structure on employee performance of coffee trading companies in Kenya. The study was guided by the positivism philosophy and used a descriptive correlational research design. The population comprised 180 senior managers of coffee trading companies in Kenya, and a sample size of 139 was determined using stratified random sampling. Primary data was collected using questionnaires. The response rate was $84 \%$. The descriptive statistics were means and standard deviations while the inferential analysis included factor analysis, correlational analysis, chi-square, and regression analysis. Results of multiple linear regression analysis revealed that supportive leadership style did not significantly predict employee performance, $R^{2}=0.001, F(1,110)=0.118, p \leq$ $.05, \beta=-0.040, p \leq .05$ but that participative leadership style significantly predicted employee performance, $R^{2}=0.865, F(1,115)=735.111, p \leq 05, \beta=0.943, p \leq 05$. Task structure was found to moderate the relationship between path-goal leadership styles and employee performance, $R^{2}=0.094$, $F(5,101)=6.92, p \leq 05, \beta=0.208, p \leq .05$. The study recommends that leaders of coffee trading companies should apply a participative leadership style with their employees with constant communication and consultation in order to achieve optimal performance.
\end{abstract}

(C) 2019 Bussecon International Academy. Hosting by SSBFNET. All rights reserved. Peer review under responsibility of Bussecon International Academy \& SSBFNET.

\section{Introduction}

Organizations exist to meet specific objectives and as a result, their success is highly dependent on the performance of employees in meeting their goals. It is therefore not surprising that leaders are constantly seeking ways to enhance employee performance. An argument posed by Kerpen (2016) is that people are not necessarily managed as they would desire to be managed and this results in varying levels of performance and staff retention. With the evolvement of the leadership discipline, many theories have emerged. One of these theories, the path-goal theory, advocates that the style of a leader has to fit with an employee and his or her work environment so that the leader can effectively guide the employees in the path to achieving the goals of the organization (House \& Mitchell, 1974). Ojokuku, Odetayo and Sajuyigbe (2014) define leadership style as the behavior of a leader and the approach used to provide direction, give guidance and motivate employees of an organization for optimal job performance. All leaders have unique styles but they do not necessarily use the same style in all situations. The path-goal theory which has been classified as a contingency theory explains leadership styles as a function of a leader, the characteristics of the followers, and the situation or circumstances the leader and employee are operating in. The path-goal theory recognizes the moderating role of subordinate and environmental factors and postulates that a leader will complement what is missing in any situation for the optimal performance and satisfaction of the employee. There are four leadership styles under the path-goal theory that a leader can use and these are the directive leadership style, the participative leadership style, the supportive leadership style and the achievement oriented leadership style. The influencing role of leadership on employee performance is undisputed. Globally, studies have demonstrated significant relationships between

\footnotetext{
* Corresponding author. Tel: +254-730-116000/300 ORCID ID: 0000-0003-3898-2364
} Peer review under responsibility of Bussecon International Academy. (C) 2019 Bussecon International. Hosting by SSBFNET- Center for Strategic Studies in Business \& Finance. All rights reserved. https://doi.org/10.20525/ijrbs.v8i5.317 
leader behaviors and components of organizational performance. Kenya gained independence in 1963, and up until 1986 coffee trading generated significant foreign exchange earnings. These earnings were Kenya's number one source of foreign exchange and accounted for 40.6 per cent of the national foreign exchange earnings (Skouw-Rasmussen, et al., 2014). Despite continued global appreciation for Kenya coffee, the performance of the once thriving coffee industry has been dismal and declining for over three decades. There are multiplayer players in the coffee industry and, while there has been a growing body of research to examine the decline, nearly all the research appears to have focused on the cooperative sector.

This study aims to examine the influence of supportive and participative path-goal leadership styles, and the moderating role of task structure on employee performance of coffee trading companies in Kenya. Therefore, this research was guided by the positivism philosophy and used a descriptive correlational research design. Despite the importance of the coffee trading companies who deal in $85 \%$ of the coffee produced in the country, the gaps in literature were evident in the area of the performance of coffee trading companies. This paper was motivated by the knowledge gaps in the area of the effects of leadership influence on the performance of employees of coffee trading companies in Kenya. The paper tested the following hypotheses:

$\mathrm{H}_{01}$ : Supportive leadership style does not have a significant influence on employee performance of coffee trading companies in Kenya.

$\mathrm{H}_{02}$ : Participative leadership style does not have a significant influence on employee performance of coffee trading companies in Kenya.

$\mathrm{H}_{03}$ : Task structure does not significantly moderate the relationship between leadership style and employee performance of coffee trading companies in Kenya.

For the text and organization of the study, a literature review highlights the related studies in the field to support the theoretical and empirical background of the study. The research and methodology part is followed by the discussion and implications of the study. Finally, this paper concludes with its fundamental contributions and suggestions to the field.

\section{Literature Review}

\section{The path-goal theory}

The Path-goal theory has evolved following studies undertaken over a period of time. It was first introduced by Evans in the year 1970, then developed by House in 1971 and refined by House again in the year 1996 (Evans, 1970; House \& Mitchell, 1974; House, 1996). Robbins and Judge (2013) describe the path goal theory as one of the most respected approaches to leadership. The path goal theory describes how a leader can provide support to subordinates on the path to goals by using specific behaviors contingent on the needs of the subordinates and the work situation. The four path-goal leadership styles are directive, supportive, participative and achievement-oriented leadership styles. The path-goal theory assumes flexibility on the part of leaders and suggests that leaders should choose behaviors that best suit subordinate needs and work situations. Essentially, a leader can help subordinates by selecting a style of leadership that provides what is missing in a particular work setting (Northouse, 2013).

\section{Supportive leadership style}

A supportive leader is friendly and accessible, cares for the well-being of subordinates, makes work pleasant, views subordinates as equals and shows them respect. Supportive leadership involves consideration of the needs of subordinates, display of concern for their welfare and creation of a friendly climate in the workplace (Yukl, 2015). Supportive leaders are friendly and approachable leaders who create a pleasant work environment where respect for one another prevails and where there is no or very low hierarchy. Supportive leadership styles are appropriate when followers have an internal locus of control, for instance where followers have high levels of skills and competencies and feel confident in their performance capabilities. In these circumstances, followers prefer to have control over how to perform their work and formal or autocratic authority is unwelcome and considered inappropriate by the individuals. Supportive leadership is also appropriate when the tasks are very simple thereby rendering any formal authority aimed at demonstrating how tasks should be performed redundant. Under these circumstances, a respectful and supportive leadership style results in greater job satisfaction. A supportive leadership style is also appropriate where tasks are stressful, boring, tedious, or dangerous, as the caring supportive behavior yields increased subordinate effort as it lowers anxiety, minimizes unpleasant aspects of the work and enhances subordinate self-confidence (Lussier and Achua, 2013).

\section{Participative leadership style}

Participative leaders consult with subordinates, obtain ideas and opinions and integrate their suggestions into decisions on how the organization will proceed (Northouse, 2013). It is most effective when subordinates are highly trained and involved in their work. The leader invites employees to give input and to share in the decision making process (Yukl, 2015). Participative leadership may also increase the intrinsic valence of the work and thus satisfaction for subordinates with a high need for achievement and autonomy. Participative leadership is appropriate in circumstances where followers desire to be involved, their levels of competencies are high and they have internal locus of control. Further, participative leadership style is also appropriate where the environmental task is complex and authority is either strong or weak and so the collaboration between the leader and co-workers enables achievement of 
the desired outcomes. A participative leadership style under these scenarios results in high job satisfaction in co-workers (Lussier \& Achua, 2013).

\section{Task structure}

Path goal theory requires that leaders should choose a style that best meets the needs of the subordinates, contingent on their environmental factors. Environment situational factors include task structure and formal authority systems. Task structure is the extent to which the nature and the requirements of the task are specified. The task structure therefore refers to the degree to which a task, job, or work assignment is simple, repetitive and unambiguous (Lussier\& Achua, 2013). The focus of the path goal theory is for the leader to help the subordinate overcome obstacles for achievement of satisfaction and performance and it can be that the task characteristics or its design necessitate the leader's support. For instance, ambiguous tasks may necessitate a leader providing more structure while complex tasks may necessitate higher need for support and guidance from the leader (Wan, 2015).

\section{Supportive leadership and employee performance}

Supportive leadership style is defined as leader behaviors that provide emotional support for employees and include expressions of concern for employees' needs and welfare (House, 1971). This section includes an empirical review of studies that demonstrate the effect of leaders deploying supportive leadership style on employee performance. The literature has been analyzed and is presented for the constructs for supportive leadership style for this study which were respect, recognition and concern for employees. When managers respect their subordinates' way of doing things and trust their ability to do their work, subordinates tend to improve their outputs (Hocine, Zhang, Song and Ye, 2014). According to Euwema, Wendt and van Emmerik (2014) trust, a vital component of leadership, has the ability to enhance the influence of the leader and therefore his or her effectiveness in motivating employees to achieving organizational goals. Trust is optimized under supportive leadership and the caring leader is able to connect with the followers by staying attuned with followers' needs and conveying concern and understanding of the follower's circumstances. A study by Hocine et al., (2014) found that respectful leaders played a crucial role in improving the financial performance of the organization. When subordinates felt they were respected and valued for their contributions, they would be motivated to work even under minimal or no supervision leading to improvement of the profitability of the organization. The recommendation from these findings were that that managers should emphasize employees' development because concern for employee personal growth resulted in employees feeling they were valued and this tremendously influenced their enthusiasm for work and resulted in high levels of performance. The findings from Aberdeen Group (2013) indicated that when leaders recognized positive behaviors of employees and demonstrated appreciation for their contributions, employees repeated those behaviors, remained engaged with the company and were motivated to keep performing. Employees whose contributions were recognized publicly felt special and were motivated to perform to optimal levels. While a large majority of the studies showed that supportive leadership style positively influenced employee performance, an important finding by Caza, Zhang, Wang and Bai (2015) revealed that the external supportive behavior demonstrated by the leader did not yield better performance in all situations. Where followers perceived their leaders were insincere, distrust followed and performance or output by them declined. Followers then felt they were being manipulated and resented the leaders who used supportive style only as a tool to achieve results from them. Leaders need to be perceived as sincere and genuinely care for their employees. This was consistent with the findings of Hassan and Ahmed (2011) who cautioned that leaders who were considered insincere and pretentious did not yield high performance from their followers. Trust in the leaders was therefore considered to be a necessary precursor for followers to perform optimally and leadership must exercise tact so as not to be perceived pretentious especially when they show care and concern to employees. Pimpa and Moore (2012) also emphasized the significance of employee perceptions of leader behavior in establishing a proper climate to draw out creativity and high performance from employees.

\section{Participative leadership style and employee job performance}

Evans (1979) defined that participative leadership as the process of having a shared influence in decision making by a leader and his or her subordinates. This section includes an empirical review of studies that demonstrate the effect of leaders deploying participative leadership style on employee performance. The literature has been analyzed and is presented for the constructs for participative leadership style which for this study which were consultation, communication and explanation. The results of a study (Pedraja-Rejas \& Rodríguez-Ponze, 2013) of 126 respondents from small and medium sized companies in Chile found that participative leadership style had a positive influence on employee effectiveness and this enhanced the percentage of tasks completed within budget. They proposed that participants are motivated by participation, by the acceptance of their opinions, suggestions and ideas in the decisionmaking process and therefore leaders should avoid making lone decisions and must collaborate with team members, provide a good work climate, be concerned with the team's well-being and treat them fairly. A study by Khuong and Hoang (2015) of 320 auditors in Vietnam also found participative leadership style was positively associated with higher motivation in employees, stronger relationships between leaders and employees. The behavior of leaders of consulting and encouraging employee participation in decision-making resulted in motivated employees who freely shared information, discussed perspectives and collectively arrived at better decisions and ideas. Sagnak (2016) found that employees valued leaders who applied participative leadership style as they felt their opinions were valued and they were included in the decision making process. Employees experienced enhanced feelings of justice and trust and these behaviors resulted in optimizing employee satisfaction and performance. On the other hand, a study by Murugesan (2012) found that the downside of using a participative style was that employees perceived the leaders as incapable of 
making decisions without them. Another downside according to Bhatti, Maitlo, Shaikh, Hashmi, and Shaikh (2012) is that the use of this style by leaders results in slowing down the pace of performance of employees. The suggestion therefore provided was that leaders should apply a participative approach when team work was considered essential and where the requirement for quality exceeded the need for speed to market. The findings of Iqbal, Anwar and Haider (2015) however found that the behavior of leaders in engaging followers, obtaining their input and integrating such input before reaching decisions actually resulted in tasks being accomplished successfully by their preset deadlines. Timmerman (2012) attributed the behavior of participative leaders in constantly deploying principles of engagement, involving employees in strategic discussions, actively listening and showing empathy to innovative ideas being evoked through the healthy discussions and found that employees were more committed to the organizational goals and gained personal growth from the participative process.

\section{Moderating role of task structure}

The literature has been analyzed and is presented for the constructs for task structure which were task complexity, challenges offered and obstacles in task execution. A study by Dindyal, Cheng and $\mathrm{Ng}$ (2012) illustrated the challenges for teachers in assisting the learning of low attaining students by responding effectively to scaffolding or supporting opportunities. Interviews were carried out with students to understand their sentiments about the tasks and the teacher's behaviors. The study also sought to assess understanding of the concepts in the lessons delivered by the teachers. The findings showed that teachers needed to have an understanding of the students' prior knowledge of the lessons and adjust their styles and approach in teaching their lessons by preparing lesson plans with content delivered in ways that would interest and challenge the students. Successful scaffolding was found to depend upon the teachers being able to bridge the students' understanding of the known and unknown. Yen (2016) carried out a study that examined obstacles that a Vietnamese teacher had to overcome in performing her role. The obstacles included lower proficiency on the part of the teacher to perform the task, institutional barriers, the psychological burden that was imposed, socialcultural barriers and finally the size of classes this teacher had to work with. The findings of the study indicated that the obstacles affected the length of time and the successful completion of tasks. The findings showed that the form in which feedback was given directly impacted on the self-esteem and confidence of the individual. Agbim (2013) carried out a study of 43 manufacturing companies in Nigeria to examine how the task structure impacted on idea generation and idea implementation. The study had 664 respondents who included both supervisors and employees. The findings showed that the structure of tasks affected the ability of leaders to generate and implement ideas. Irving (2014) studied the behavior applied by leaders when employees performed varied tasks and found that when tasks were complex, the directive leadership style contributed significantly to improving employee satisfaction with the leader and increasing employee motivation and overall job satisfaction. On the other hand, when tasks involved duties that were perceived to be dangerous, a supportive leadership style was found to be more effective for employee commitment and performance.

\section{Conceptual Framework}

Conceptual frameworks, as defined by Marshall and Rossman (2016), are mental maps inferred or derived from specific illustrations or circumstances that help to show the relationships between interplay of variables graphically and diagrammatically. This conceptual framework is illustrated below and comprises of the independent variables which are supportive and participative leadership styles. The moderating variable is task structure and the dependent variable is employee performance.

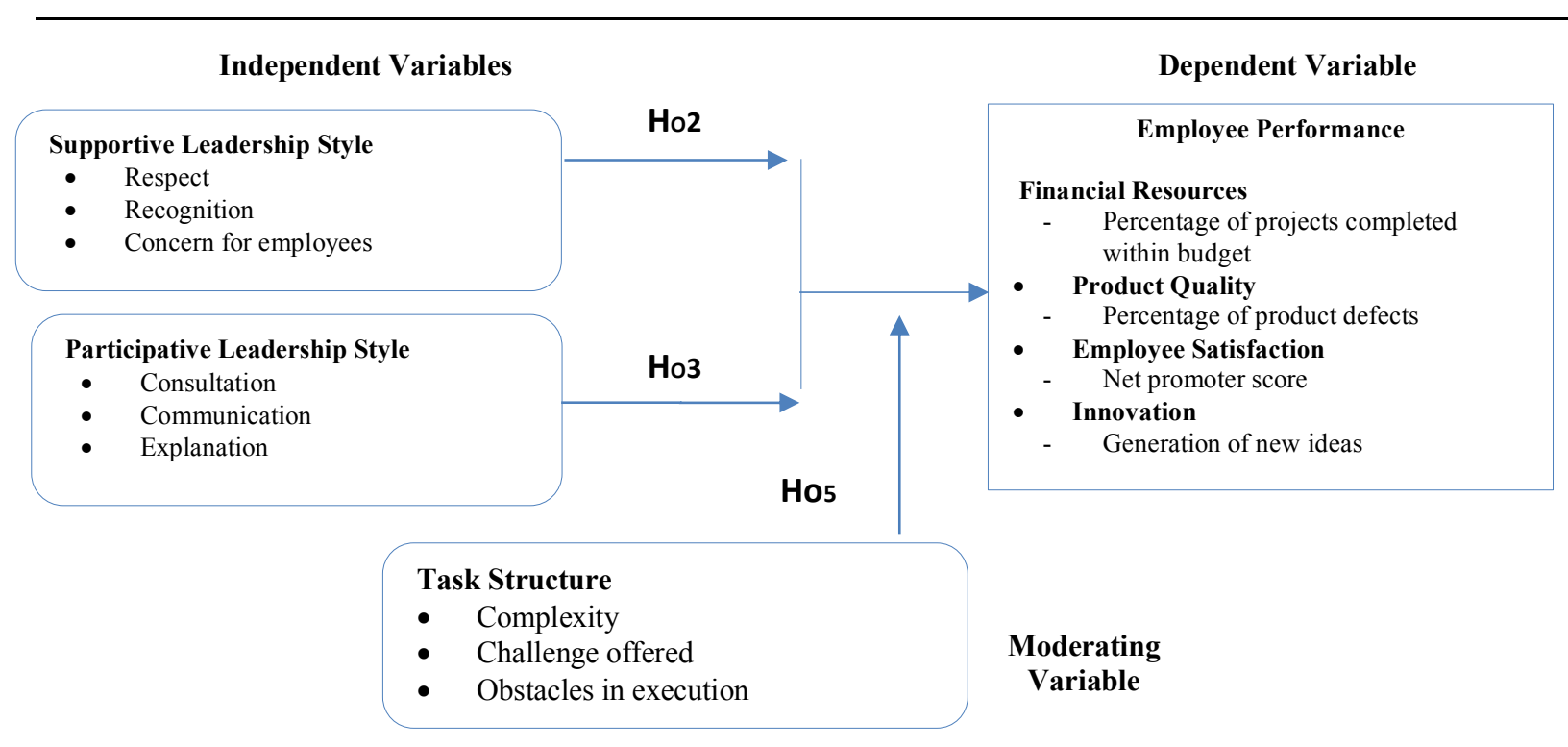

Figure 1: Conceptual framework 


\section{Research and Methodology}

This section illustrates the research philosophy, research design, target population, sampling design, data collection and data analysis methods used in the study. The research philosophy adopted was positivism. The study adopted descriptive correlational research design to analyze the data collected and test the hypothesis. The population of the study was 180 senior managers and a sample size of 139 managers was arrived at using stratified random sampling. The data was collected using self-administered questionnaire and then analyzed using descriptive and inferential statistics. The response rate was $84 \%$. The descriptive statistics were mean and standard deviation while the inferential analysis included factor analysis, correlational analysis, chi-square and regression analysis.

\section{Demographic information}

Of the total respondents, $26.5 \%$ were finance managers, $21.4 \%$ were quality control managers, $23.1 \%$ were trading managers and $29.0 \%$ were human resource managers. In terms of gender, $48.7 \%$ were female while 51.3 were male. $17 \%$ of the respondents were over 55 years, about $59 \%$ were in the 41 to 55 years age bracket, $23 \%$ were in the 26 to 40 years age bracket and $1 \%$ were in the 18 to 25 years age bracket.

\section{Supportive leadership style and employee performance}

\section{Descriptive Analysis}

The descriptive analysis conducted for the influence for supportive leadership style on employee performance is summarized in Table 1 below.

Table 1: Mean and standard deviation for supportive leadership

\begin{tabular}{|c|c|c|c|}
\hline Supportive Leadership Style & $\mathbf{N}$ & (M) & (SD) \\
\hline My supervisor respects the employees in our organization & 114 & 4.17 & .775 \\
\hline My supervisor recognizes employees for their achievements & 114 & 4.18 & .779 \\
\hline My supervisor shows concern for employees & 112 & 4.19 & .822 \\
\hline \multicolumn{4}{|c|}{ Influence of Supportive Leadership Style on effective use of Financial Resources by Employees } \\
\hline $\begin{array}{l}\text { To what extent does the respect your supervisors have for employees influence the } \\
\text { effective use of financial resources by employees in your organization? }\end{array}$ & 112 & 2.63 & 1.107 \\
\hline $\begin{array}{l}\text { To what extent does recognition of employee achievements by your supervisor influence } \\
\text { the effective use of financial resources by employees in your organization? }\end{array}$ & 112 & 2.76 & 1.109 \\
\hline $\begin{array}{l}\text { To what extent does you're the concern for employees by your supervisor influence the } \\
\text { effective use of financial resources by employees in your organization? }\end{array}$ & 112 & 2.73 & 1.090 \\
\hline \multicolumn{4}{|l|}{ Influence of Supportive Leadership Style on Product Quality Produced by Employees } \\
\hline $\begin{array}{l}\text { To what extent does respect by your supervisor for employees influence the quality of } \\
\text { products produced by employees in your organization? }\end{array}$ & 112 & 2.04 & 1.378 \\
\hline $\begin{array}{l}\text { To what extent does recognition of employee achievements by your supervisor influence } \\
\text { the quality of products produced by employees in your organization? }\end{array}$ & 112 & 2.05 & 1.400 \\
\hline $\begin{array}{l}\text { To what extent does your supervisor's concern for employees influence the quality of } \\
\text { products produced by employees in your organization? }\end{array}$ & 112 & 2.04 & 1.375 \\
\hline \multicolumn{4}{|l|}{ Influence of Supportive Leadership Style on Employee Satisfaction } \\
\hline $\begin{array}{l}\text { Considering the respect your supervisor has for employees, how likely are you to refer } \\
\text { friends and family to work in your organization? }\end{array}$ & 107 & 4.29 & .456 \\
\hline $\begin{array}{l}\text { Considering the recognition of employee achievements by your supervisor, how likely } \\
\text { are you to refer friends and family to work in your organization? }\end{array}$ & 107 & 4.35 & .497 \\
\hline $\begin{array}{l}\text { Considering the concern for employees by your supervisor, how likely are you to refer } \\
\text { friends and family to work in your organization? }\end{array}$ & 107 & 4.22 & .441 \\
\hline \multicolumn{4}{|l|}{ Influence of Supportive Leadership Style on Innovation } \\
\hline $\begin{array}{l}\text { To what extent does respect for employees by your supervisor influence the generation } \\
\text { of new ideas in your organization? }\end{array}$ & 107 & 2.04 & 1.205 \\
\hline $\begin{array}{l}\text { To what extent does recognition of employee achievements by your supervisor influence } \\
\text { the generation of new ideas by employees in your organization? }\end{array}$ & 107 & 2.17 & 1.277 \\
\hline $\begin{array}{l}\text { To what extent does the concern for employees by your supervisor influence the } \\
\text { generation of new ideas by employees in your organization? }\end{array}$ & 107 & 2.03 & 1.193 \\
\hline
\end{tabular}

Source: Authors 
The findings revealed that on average, the managers were neutral in their opinion on whether or not recognition of the employee achievements influences the effective use of financial resources $(\mathrm{M}=2.76, \mathrm{SD}=1.109)$, managers disagreed that concern for employees by supervisors' concern influences the quality of products produced $(\mathrm{M}=2.04, \mathrm{SD}=1.375)$. The findings further revealed that managers agreed that, on considering the recognition of employees by supervisors, they are very likely to refer friends and families to work in the organization $(\mathrm{M}=4.35, \mathrm{SD}=0.497)$ but disagreed that the respect supervisor showed for employees influences the generation of new ideas $(\mathrm{M}=2.04, \mathrm{SD}=1.205)$.

\section{Correlation between supportive leadership style and employee performance}

The results in Table 2 show the Pearson's correlation coefficients results which reveal that supportive leadership style did not significantly relate to employee performance $\mathrm{r}(112)=-0.33, \mathrm{p} \leq .05$.

Table 2: Correlation between supportive leadership style and employee performance

\begin{tabular}{llll}
\hline & & Supportive Leadership & \multicolumn{1}{c}{ Employee Performance } \\
\hline Supportive Leadership & Pearson Correlation & 1 & -.033 \\
\cline { 2 - 4 } & Sig. (2-tailed) & & .731 \\
\cline { 2 - 4 } & $\mathrm{N}$ & 114 & 112 \\
\hline Employee Performance & Pearson Correlation & -.033 & 1 \\
\cline { 2 - 4 } & Sig. (2-tailed) & .731 & 112 \\
\cline { 2 - 3 } & $\mathrm{N}$ & 112 & \\
\hline
\end{tabular}

Source: Authors

\section{Chi-square test on supportive leadership style}

The study sought to examine whether there was a statistically significant association between supportive leadership style and employee performance. The results of the Chi-square test did not indicate the existence of a statistically significant association between supportive leadership style and employee performance $\chi^{2}(48, N=117)=131.748, p \leq .05$.

\section{Regression Analysis and Hypothesis Testing}

Based on a bivariate linear regression model, the study sought to establish the effect of supportive leadership style on employee performance among senior managers of coffee trading companies in Kenya. The study tested the hypothesis:

$\mathbf{H}_{\mathbf{0 1}}$ : Supportive leadership style does not have a significant effect on employee performance of coffee trading companies in Kenya.

The results in Table 3 indicate that supportive leadership style explained $0.01 \%$ variation in employee performance among the senior managers of coffee trading companies, $R^{2}=.001$. Therefore, only $0.1 \%$ of the changes in employee performance among senior managers could be explained by the supportive leadership style.

Table 3: Regression model summary for supportive leadership style

Model Summary

\begin{tabular}{lllll}
\hline Model & $\mathrm{R}$ & R Square & Adjusted R Square & Std. Error of the Estimate \\
\hline $\mathbf{1}$ & $.033^{\mathrm{a}}$ & .001 & -.008 & .917 \\
\hline
\end{tabular}

Source: Author

Table 4 presents the results of the regression ANOVA for supportive leadership style and employee performance and these findings indicate that the model was not statistically significant in linking supportive leadership style and employee performance among senior managers of coffee trading companies in Kenya, $F(1,110)=0.118, p \leq .05$. Thus, the findings indicate that the effect of supportive leadership style on employee performance was not significant. The model was important in explaining the relationship and considering the importance of F-statistic, the null hypothesis was accepted.

Table 4: Regression ANOVA for supportive leadership style

\begin{tabular}{lllllll}
\hline \multicolumn{2}{l}{ ANOVA $^{\mathrm{a}}$} & & & & \\
\hline \multicolumn{2}{l}{ Model } & Sum of Squares & df & Mean Square & F & Sig. \\
\hline \multirow{1}{1}{} & Regression & .100 & 1 & .100 & .118 & $.731^{\mathrm{b}}$ \\
\cline { 2 - 8 } & Residual & 92.594 & 110 & .842 & & \\
\cline { 2 - 9 } & Total & 92.694 & 111 & & & \\
\hline
\end{tabular}

Source: Author 
Multiple linear regression analysis was conducted with the purpose of determining the magnitude and direction of the relationship between achievement-oriented leadership style and employee performance of senior managers of coffee trading companies in Kenya.

Table 5: Regression coefficients for supportive leadership style

\begin{tabular}{|c|c|c|c|c|c|c|}
\hline \multicolumn{7}{|c|}{ Coefficients $^{\mathrm{a}}$} \\
\hline \multirow{2}{*}{\multicolumn{2}{|c|}{ Model }} & \multicolumn{2}{|c|}{ Unstandardized Coefficients } & Standardized Coefficients & \multirow[t]{2}{*}{$\mathrm{t}$} & \multirow[t]{2}{*}{ Sig. } \\
\hline & & B & Std. Error & Beta & & \\
\hline \multirow[t]{2}{*}{1} & (Constant) & 2.908 & .491 & & 5.920 & .000 \\
\hline & Supportive Leadership & .040 & .116 & .033 & .344 & .731 \\
\hline
\end{tabular}

Source: Authors

The results in Table 5 indicate that supportive leadership style did not significantly predict employee performance, $\beta=.040, \mathrm{t}(111)$ $=0.344, p \leq 05$. Therefore, a unit increase in supportive leadership style would not lead to a significant increase in employee performance among the senior managers of coffee trading companies in Kenya. The study therefore concluded that supportive leadership style did not significantly predict employee performance of senior managers of coffee trading companies in Kenya.

\section{Participative leadership style and employee performance}

\section{Descriptive analysis}

The descriptive analysis conducted for the influence for participative leadership style on employee performance is summarized in Table 6 below.

Table 6: Mean and standard deviation of participative leadership style

\begin{tabular}{|c|c|c|c|}
\hline Participative Leadership Style & $\mathrm{N}$ & (M) & SD) \\
\hline In my company, my supervisor consults employees to discuss problems and generate workable solutions & 117 & 3.98 & .731 \\
\hline In my company, my supervisor regularly communicates with employees on developments & 117 & 3.92 & .721 \\
\hline In my company, my supervisor listens to explanations from employees & 117 & 4.08 & .709 \\
\hline \multicolumn{4}{|l|}{ Influence of Participative Leadership Style on the effective use of Financial Resources } \\
\hline $\begin{array}{l}\text { To what extent does the consultation between your supervisor and employees to discuss problems and generate } \\
\text { workable solutions influence the effective use of financial resources by employees in your organization? }\end{array}$ & 117 & 3.12 & .618 \\
\hline $\begin{array}{l}\text { To what extent does regular communication between your supervisor and employees on all developments influence the } \\
\text { effective use of financial resources by employees in your organization? }\end{array}$ & 117 & 3.12 & .659 \\
\hline $\begin{array}{l}\text { To what extent does the role played by your supervisor in listening to explanations from employees influence the } \\
\text { effective use of financial resources by employees in your organization? }\end{array}$ & 117 & 3.12 & .632 \\
\hline \multicolumn{4}{|l|}{ Influence of Participative Leadership Style on Product Quality Produced by Employees } \\
\hline $\begin{array}{l}\text { To what extent do consultations between your supervisor and employees in discussing problems and generating } \\
\text { workable solutions influence the quality of products produced by employees in your organization? }\end{array}$ & 117 & 1.64 & 1.133 \\
\hline $\begin{array}{l}\text { To what extent does regular communication between your supervisors and the employees on all developments influence } \\
\text { the quality of products produced by employees in your organization? }\end{array}$ & 117 & 1.67 & 1.167 \\
\hline $\begin{array}{l}\text { To what extent does the role played by your supervisor in listening to explanations from employees influence the quality } \\
\text { of products produced by employees in your organization? }\end{array}$ & 117 & 1.69 & 1.102 \\
\hline \multicolumn{4}{|l|}{ Influence of Participative Leadership Style on Employee Satisfaction } \\
\hline $\begin{array}{l}\text { Considering the consultation by your supervisor of employees to discuss problems and generate workable solutions, } \\
\text { how likely are you to refer friends and family to work in your organization? }\end{array}$ & 117 & 4.21 & .518 \\
\hline $\begin{array}{l}\text { Considering the regular communication on developments between your supervisor and employees, how likely are you } \\
\text { to refer friends and family to work in your organization? }\end{array}$ & 117 & 4.20 & .513 \\
\hline $\begin{array}{l}\text { Considering how your supervisor listens to explanations from employees, how likely are you to refer friends and family } \\
\text { to work in your organization? }\end{array}$ & 117 & 4.20 & .495 \\
\hline \multicolumn{4}{|l|}{ Influence of Participative Leadership Style on Innovation } \\
\hline $\begin{array}{l}\text { To what extent does consultation of employees by your supervisor for problem solving to generate workable solutions } \\
\text { influence the generation of new? }\end{array}$ & 117 & 2.52 & .847 \\
\hline $\begin{array}{l}\text { To what extent does regular communication between your supervisor and employees on all developments influence the } \\
\text { generation of new ideas by employees in your organization? }\end{array}$ & 117 & 2.40 & .708 \\
\hline $\begin{array}{l}\text { To what extent does listening to explanations of the employees by your supervisor influence the generation of new } \\
\text { ideas by employees? }\end{array}$ & 117 & 2.38 & .668 \\
\hline
\end{tabular}

The results in Table 6 indicate that, on average, the respondents agreed that consultation between supervisors and employees to discuss problems and generate workable solutions influences the effective use of financial resources by employees in the organization $(\mathrm{M}=3.12$, S.D $=0.618)$; managers disagreed that regular communication between supervisors and the employees on developments influences the quality of products produced $(\mathrm{M}=1.67, \mathrm{~S} . \mathrm{D}=1.167)$; managers agreed that, considering how supervisors listen to 
explanations from employees, they were very likely to refer friends and family to work in the organization $(M=4.20, S . D=0.513)$; managers were neutral on whether or not consultation by their supervisors to discuss problems and generate workable solutions influences the generation of new ideas $(\mathrm{M}=2.52, \mathrm{SD}=0.847)$.

\section{Correlations between participative leadership style and employee performance}

Table 8: Correlations between participative leadership style and employee performance

\begin{tabular}{|c|c|c|c|c|}
\hline \multicolumn{5}{|l|}{ Correlations } \\
\hline & & $\begin{array}{l}\text { Participative } \\
\text { Style }\end{array}$ & Leadership & Employee Performance \\
\hline \multirow{3}{*}{$\begin{array}{l}\text { Participative } \\
\text { Leadership Style }\end{array}$} & Pearson Correlation & 1 & & $.956^{* *}$ \\
\hline & Sig. (2-tailed) & & & .000 \\
\hline & $\mathrm{N}$ & 117 & & 117 \\
\hline \multirow{3}{*}{$\begin{array}{l}\text { Employee } \\
\text { Performance }\end{array}$} & Pearson Correlation & $.956^{* *}$ & & 1 \\
\hline & Sig. (2-tailed) & .000 & & \\
\hline & $\mathrm{N}$ & 117 & & 117 \\
\hline
\end{tabular}

\section{Source: Authors}

The result of the Pearson's correlation coefficient reveals a strong positive and significant correlation between participative leadership style and employee performance $\mathrm{r}(117)=.956, \mathrm{p} \leq .05$.

\section{Chi-square test on participative leadership style and employee performance}

The findings of the study show the results of the Pearson's chi-square test indicated that there was sufficient evidence to conclude that there is a statistical significant association between participative leadership style and employee performance $\chi^{2}(133, N=117)=$ $590.06, p \leq .05$.

\section{Regression analysis and Hypothesis Testing}

Linear regression assesses the extent a predictor variable explains a dependent variable. The magnitude and direction of the measure provides information on the extent to which changes in a variable affect the response variable. Based on a bivariate linear regression model, the study sought to establish the effect of participative leadership style on employee performance among senior managers of coffee trading companies in Kenya. The study tested the hypothesis:

$\mathbf{H}_{03}$ : Participative leadership style does not have a significant effect on employee performance of coffee trading companies in Kenya.

The results in Table 9 indicate that participative leadership style explained $86.5 \%$ variation in employee performance among the senior managers of coffee trading companies, $R^{2}=.865$.

Table 9: Regression model summary for participative leadership style

\begin{tabular}{lllll}
\hline \multicolumn{2}{l}{ Model Summary } & & \\
\hline Model & $\mathrm{R}$ & $\mathrm{R}$ Square & Adjusted R Square & Std. Error of the Estimate \\
\hline $\mathbf{1}$ & $.930^{\mathrm{a}}$ & .865 & .864 & .270 \\
\hline
\end{tabular}

Source: Authors

This implies that $86.5 \%$ of the changes in employee performance among senior managers could be explained by the participative leadership style.

Table 10 presents the results of the regression ANOVA for participative leadership style and employee performance and these findings indicate that the model was statistically significant in linking participative leadership style and employee performance among senior managers of coffee trading companies in Kenya, $F(1,115)=735.111, p \leq .05$. Thus, the findings indicate that the effect of participative leadership style on employee performance was statistically significant. The model was significant in giving explanation on the relationship. Basing on the significance of the F-statistic, the null hypothesis was rejected and the alternative hypothesis that participative leadership styles significantly influences employee performance was accepted. 
Table 10: Regression ANOVA for participative leadership style

\begin{tabular}{lllllll}
\hline \multicolumn{2}{l}{ ANOVA $^{\mathrm{a}}$} & \multicolumn{5}{l}{} \\
\hline \multicolumn{2}{l}{ Model } & Sum of Squares & df & Mean Square & F & Sig. \\
\hline $\mathbf{1}$ & Regression & 53.583 & 1 & 53.583 & 735.111 & $.000^{\mathrm{b}}$ \\
\cline { 2 - 7 } & Residual & 8.383 & 115 & .073 & & \\
\cline { 2 - 7 } & Total & 61.966 & 116 & & & \\
\hline
\end{tabular}

a. Dependent Variable: Employee performance

b. Predictors: (Constant), Participative leadership

Source: Authors

Multiple linear regression was conducted with the purpose of determining the magnitude and direction of the relationship between participative leadership style and employee performance of senior managers of coffee trading companies in Kenya.

Table 11: Regression coefficients for participative leadership style

\begin{tabular}{|c|c|c|c|c|c|c|}
\hline \multicolumn{7}{|c|}{ Coefficients $^{\mathrm{a}}$} \\
\hline \multirow{2}{*}{\multicolumn{2}{|c|}{ Model }} & \multicolumn{2}{|c|}{ Unstandardized Coefficients } & \multirow{2}{*}{$\begin{array}{l}\text { Standardized Coefficients } \\
\text { Beta }\end{array}$} & \multirow[t]{2}{*}{$\mathrm{t}$} & \multirow[t]{2}{*}{ Sig. } \\
\hline & & $\mathrm{B}$ & Std. Error & & & \\
\hline \multirow[t]{2}{*}{1} & (Constant) & .285 & .139 & & 2.056 & .042 \\
\hline & Participative leadership & .943 & .035 & .930 & 27.113 & .000 \\
\hline
\end{tabular}

a. Dependent Variable: Employee performance

Source: Authors

The results in Table 11 indicates that participative leadership style positively and significantly predicted employee performance, $\beta=$ $0.943, t(116)=27.113, p \leq .05$. This implies that a unit increase in participative leadership style would lead to a significant increase in employee performance among the senior managers of coffee trading companies in Kenya by 0.943 units. The study hence concluded that participative leadership style positively and significantly predicted employee performance of senior managers of coffee trading companies in Kenya.

\section{Moderating influence of task structure}

\section{Correlations between task structure and employee performance}

The Pearson's correlation coefficient reveals that there was a moderate positive and significant correlation overall between task structure and employee performance $r(110)=.413, p \leq .05$.

Table 12: Correlations between task structure and employee performance

\begin{tabular}{llll}
\hline Correlations & & Task Structure & Employee Performance \\
\hline Task Structure & Pearson Correlation & 1 & $.413^{* *}$ \\
\cline { 2 - 4 } & Sig. (2-tailed) & & .000 \\
\cline { 2 - 4 } & $\mathrm{N}$ & 110 & 110 \\
\hline \multirow{2}{*}{ Employee Performance } & Pearson Correlation & $.413^{* *}$ & 1 \\
\cline { 2 - 4 } & Sig. (2-tailed) & .000 & 117 \\
\cline { 2 - 3 } & $\mathrm{N}$ & 110 & \\
\hline
\end{tabular}

\section{Source: Authors}

\section{Chi-square test for task structure and employee performance}

The study sought to examine whether there was a statistically significant association between task structure and employee performance. The results of the study showed there was sufficient evidence to conclude that there is a statistical significant association between task structure and employee performance $\chi^{2}(80, \mathrm{~N}=117)=393.252, \mathrm{p} \leq .05$.

\section{Regression analysis and hypothesis testing}

The study sought to determine the moderating influence of task structure on the relationship between path-goal leadership styles and employee performance of the senior managers of coffee trading companies in Kenya. The following hypothesis was therefore tested:

H03: Task structure does not moderate the relationship between path-goal leadership styles and employee performance among the senior managers of coffee trading companies in Kenya. 
Table 13: Regression model summary after moderation

\begin{tabular}{|c|c|c|c|c|c|c|c|c|c|}
\hline \multirow[t]{2}{*}{ Model } & \multirow[t]{2}{*}{$\mathbf{R}$} & \multirow{2}{*}{$\begin{array}{l}\mathbf{R} \\
\text { Square }\end{array}$} & \multirow{2}{*}{$\begin{array}{l}\text { Adjusted R } \\
\text { Square }\end{array}$} & \multirow{2}{*}{$\begin{array}{l}\text { Std. Error } \\
\text { of the } \\
\text { Estimate }\end{array}$} & \multicolumn{5}{|c|}{ Change Statistics } \\
\hline & & & & & $\begin{array}{l}\mathrm{R} \text { Square } \\
\text { Change }\end{array}$ & F Change & df1 & df2 & $\begin{array}{l}\text { Sig. F } \\
\text { Change }\end{array}$ \\
\hline 1 & $.402^{\mathrm{a}}$ & .161 & .128 & .23352 & .161 & 4.902 & 4 & 102 & .001 \\
\hline 2 & $.505^{\mathrm{b}}$ & .255 & .218 & .22114 & .094 & 12.736 & 1 & 101 & .001 \\
\hline
\end{tabular}

a. Predictors: (Constant), Participative Leadership Style, Supportive Leadership

b. Predictors: (Constant), Participative Leadership Style, Supportive Leadership, Task Structure

Source: Authors

The findings presented in Table 13 indicate that task structure explained 9.4\% variation in moderating the relationship between pathgoal leadership styles and employee performance among the senior managers of coffee trading companies, $\mathrm{R} 2=.094$. This implied that $9.4 \%$ of the changes in employee performance among senior managers could be explained by task structure. Table 14 shows that the relationship between task structure, path-goal leadership styles and employee performance was significant, $F(1,101)=6.920$, $p$ $\leq .05$.

Table 14: Regression ANOVA after moderation

\begin{tabular}{lllllll}
\hline Model & & Sum of Squares & Df & Mean Square & F & Sig. \\
\hline $\mathbf{1}$ & Regression & 1.069 & 4 & .267 & 4.902 & $.001^{\mathrm{b}}$ \\
\cline { 2 - 7 } & Residual & 5.562 & 102 & .055 & & \\
\cline { 2 - 7 } & Total & 6.632 & 106 & & 6.920 & $.000^{\mathrm{c}}$ \\
\hline $\mathbf{2}$ & Regression & 1.692 & 5 & .338 & .049 & \\
\cline { 2 - 7 } & Residual & 4.939 & 101 & & \\
\cline { 2 - 7 } & Total & 6.632 & 106 & & & \\
\end{tabular}

a. Dependent Variable: Overall Employee Performance

b. Predictors: (Constant), Participative Leadership Style, Supportive Leadership

c. Predictors: (Constant), Participative Leadership Style, Supportive Leadership, Task Structure

Source: Authors

The model was significant in moderating the relationship between path-goal leadership styles and employee performance among senior managers of coffee trading companies in Kenya. In addition, the findings indicate that task structure was a good predictor of employee performance among the senior managers. The study concluded that the model was important in explaining the relationship. Considering the significance of F-statistic, the null hypothesis was rejected.

Table 15: Regression coefficients after moderation

\begin{tabular}{|c|c|c|c|c|c|c|}
\hline \multirow[t]{2}{*}{ Model } & & \multicolumn{2}{|c|}{$\begin{array}{l}\text { Unstandardized } \\
\text { Coefficients }\end{array}$} & \multirow{2}{*}{$\begin{array}{l}\text { Standardized } \\
\text { Coefficients }\end{array}$} & \multirow[t]{2}{*}{$\mathbf{t}$} & \multirow[t]{2}{*}{ Sig. } \\
\hline & & $\mathrm{B}$ & Std. Error & & & \\
\hline \multirow[t]{3}{*}{1} & (Constant) & 3.108 & .306 & & 10.174 & .000 \\
\hline & Supportive Leadership & -.025 & .046 & -.077 & -.555 & .580 \\
\hline & Participative Leadership Style & .110 & .046 & .311 & 2.379 & .019 \\
\hline \multirow[t]{4}{*}{2} & (Constant) & 2.574 & .326 & & 7.900 & .000 \\
\hline & Supportive Leadership & .025 & .046 & .076 & .550 & .583 \\
\hline & Participative Leadership Style & .058 & .046 & .163 & 1.252 & .213 \\
\hline & Task Structure & .208 & .058 & .349 & 3.569 & .001 \\
\hline
\end{tabular}

\section{Source: Author}

Multiple linear regression analysis was conducted with an aim of determining the magnitude and direction of the moderating relationship of task structure on path-goal leadership styles and employee performance of senior managers of coffee trading companies in Kenya.

The study findings in Table 15 revealed that task structure positively and significantly moderated the relationship between path-goal leadership styles and employee performance, $\beta=.208, \mathrm{t}(106)=3.569, \mathrm{p} \leq .05$. 
This implied that a unit increase in moderating influence of task structure would lead to an increase employee performance among the senior managers by about 0.208 units. Thus, the study concluded that task structure positively and significantly moderated between path-goal leadership styles and employee performance of senior managers of coffee trading companies in Kenya.

\section{Result and Discussion}

For the first objective, the multiple regression analysis results revealed that supportive leadership style did not significantly predict employee performance, $\mathrm{R} 2=0.001, \mathrm{~F}(1,110)=0.118, \mathrm{p} \leq .05, \beta=-0.040, \mathrm{p} \leq .05$. Correlation analysis also showed the relationship between supportive leadership style and employe performance was not significant, $\mathrm{r}(112)=-0.033, \mathrm{p} \leq .05$ and the Chi-Square test results also revealed no association between supportive leadership style and employee performance, $\chi^{2}(48, \mathrm{~N}=117)=131.748, \mathrm{p} \leq$ 0.05 . The statistical evidence was sufficient not to reject the first hypothesis that supportive leadership style did not have a significant relationship with employee performance.

Interestingly, the findings on the influence of supportive leadership style on employee performance contradict the findings of a number of studies. Shin et al. (2016) who explored the multilevel dynamics involving team leaders' supportive leadership style and the number of projects completed within budget found that supportive leadership style positively and significantly affected the number of projects completed within budget. Khalid and Irshad (2015) also found that supportive leadership style negatively affected job stress for employees leading to greater job satisfaction and this positively affected their performance. Euwema et al. (2014) found that sensitivity to individual and group needs, care for individuals and a focus on harmonic working relations by leaders resulted in improved employee performance. However, a study by Hassan and Ahmed (2011) revealed that leaders were only effective when employees perceived their behaviors and actions as sincere and authentic. Subordinate trust for a leader is a vital component and where employees did not have trust for their leaders, supportive leadership style did not result in enhanced performance. This study did not examine the level of trust employees had for their leaders, and it is not possible to assertively determine the mediating role of such subordinate factors for this study. For the second objective, results of multiple linear regression analysis revealed that participative leadership style significantly predicted employee performance, $\mathrm{R} 2=0.865, \mathrm{~F}(1,115)=735.111, \mathrm{p} \leq .05, \beta=0.943$, $\mathrm{p} \leq .05$. Correlation analysis indicated that participative leadership style positively and significantly predicted employee performance, $\beta=0.943, \mathrm{t}(116)=27.113, \mathrm{p} \leq .05$ and the results of the Chi-Square test revealed a significant association between participative leadership style and employee performance of senior managers of coffee trading companies in Kenya, $\chi^{2}(133, N=117)=590.06, p$ $\leq .05$ The statistical evidence was sufficient to reject the second hypothesis that participative leadership style did not have a significant relationship with employee performance. The results of this study concur with the findings of Ijah (2012), who studied the effects of leadership styles of secondary school principals on the staff and found that participative leadership style had a positive and significant relationship with job performance, $(r=0.8114)$. The findings also agree with those of Pedraja-Rejas et al. (2013) who revealed that participative leadership style had a positive influence on employee effectiveness measured by the percentage of tasks completed within budget. The findings of the study however disagreed with those of Bhatti et al. (2012) whose findings indicated that participative leadership style resulted in a slower pace of employee performance.

For the final objective, results of the multiple regression analysis after moderation revealed that task structure moderated the relationship between path-goal leadership styles and employee performance, $R 2=0.094, F(5,101)=6.92, p \leq .05, \beta=0.208, p \leq .05$. The findings of the study concur with those of Michael, Robert and Duane (2014) who found that that in highly structured situations, attempts by a leader to issue additional instructions had a backlash and adversely affect the morale and performance of employees. The findings also agreed with those of Spreier, Fontaine and Malloy. (2016) who found that when the tasks were non-routine and complex, an instrumental leadership style was appropriate as it assisted subordinate employees to perform their tasks more effectively. Finally, the study findings agreed with those of Irving (2014) who found that, when tasks involved duties that were perceived to be dangerous, a supportive leadership style was found to be more effective for employee commitment and performance.

\section{Conclusions}

In this study, it has been examined the influence of supportive and participative path-goal leadership styles, and the moderating role of task structure on employee performance of coffee trading companies in Kenya. The empirical study was guided by the positivism philosophy using a descriptive correlational research design. The descriptive statistics were means and standard deviations while the inferential analysis included factor analysis, correlational analysis, chi-square, and regression analysis. It has been revealed that supportive leadership style did not significantly predict employee performance, $R^{2}=0.001, F(1,110)=0.118, p \leq .05, \beta=-0.040, p$ $\leq .05$ but that participative leadership style significantly predicted employee performance, $\mathrm{R}^{2}=0.865, \mathrm{~F}(1,115)=735.111, \mathrm{p} \leq .05, \beta$ $=0.943, \mathrm{p} \leq 05$. Task structure was found to moderate the relationship between path-goal leadership styles and employee performance, $\mathrm{R}^{2}=0.094, \mathrm{~F}(5,101)=6.92, \mathrm{p} \leq .05, \beta=0.208, \mathrm{p} \leq .05$. The study, therefore, recommends that leaders of coffee trading companies should apply a participative leadership style with their employees with constant communication and consultation in order to achieve optimal performance. This research concludes (i) supportive leadership style does not have a significant influence on employee performance of coffee trading companies in Kenya, (ii) participative leadership style has a significant influence on employee performance of coffee trading companies in Kenya, (iii) task structure moderates the relationship between leadership styles and employee performance of coffee trading companies in Kenya. 


\section{References}

Aberdeen Group. (2013). The power of employee recognition, Analyst Insight, pp 1-5. Retrieved from http://go.globoforce.com/rs/globoforce/images/AberdeenReportNovember2013.pdf

Agbim, K. C. (2013). The Impact of Organizational Structure and Leadership Styles on Innovation. IOSR Journal of Business and Management (IOSR-JBM), 6(6),56-63.

Bhatti, N., Maitlo, G. M., Shaikh, N, \& Hashmi, M. A., Shaikh, F. M. (2012). The impact of democratic and autocratic leadership styles on job Satisfaction, International Business Research, Vol 5(2), DOI: 10.5539/ibr.V5n2p192.

Caza, A., Zhang, G., Wang, L., \& Bai, Y. (2015). How do you really feel? Effects of leaders' perceived emotional sincerity on followers' trust. The Leadership Quarterly, 26(4), pp 518-531. https://doi.org/10.1016/j.leaqua.2015.05.008

Dindyal, J., Cheng, L. P., \& Ng, S. L. (2012). Mathematics education: Expanding horizons (Proceedings of the 35th annual conference of the Mathematics Education Research Group of Australasia). Singapore: MERGA. Mathematics Education Research Group of Australasia

Euwema, M. C., Wendt, H., \& Van Emmerick, H. (2014). Leadership styles and group organizational citizenship across cultures. Journal of Organizational Behavior, 1035-1057.

Evans, M. G. (1970). Leadership and motivation:a core concept. Academy of management journal, 13, 91-102.

Evans, M. G. (1979). Leadership in S. Kerr (Ed.), Organizational behavior. Columbus, OH: Grid Publishing.

Hassan, A., \& Ahmed, F. (2011). Authentic leadership, trust and work engagement, International Journal of Economics and Management Engineering, 5(8), ISNI:0000000091950263

Hocine, Z., Zhang, J., Song, Y., \& Ye, L. (2014). Autonomy-Supportive Leadership Contents. Open Journal of Social Sciences, , 433-440.

House, R. J., \& Dessler, G. (1974). The path goal theory of leadership: A theoretical and empirical analysis. Management Journal (Pre-1986), 20(3), 398.

House, R. (1996). Path goal theory of leadership: Lessons, legacy and a reformulated Theory. Leadership Quarterly, 7(3), 323-352.

Ijah, A. (2012). Leadership styles of principals and job performance of staff in secondary schools in Delta state of Nigeria. An international journal of arts and humanities, Vol 2, 224-245. ISSN 2225-8590.

Irving, J. A. (2014). The Development and Initial Testing of the Purpose in Leadership Inventory: A Tool for Assessing Leader Goal-Orientation, Follower-Focus, and Purpose-in-Leadership. Servant Leadership:. Theory \& Practice, 1(1), 53-67.

Iqbal, N., Anwar, S., \& Haider, N. (2015). Effects of leadership style on employee performance. Arabian journal of business management review, 5(146).

Kerpen, D. (2016). 11 Leaders reveal how they want to be managed, retrieved from https://www.linkedin.com/pulse/11-leadersreveal-how-want-managed-dave-kerpen/

Khalid, S., \& Irshad, M. Z. (2015). Job Satisfaction among Bank Employees in Punjab, Pakistan: A Comparative Study. European journals of social sciences, 17 (4), 570-577.

Khuong, M. N., \& Hoang, M. D. (2015). The effects of leadership styles on employee motivation in auditing companies in Ho Chi Minh City, Vietnam. International Journal of trade, economics and finance, 6( 4), 210-217.

Lussier, R. N., \& Achua, C. F. (2013). Leadership: Theory, Application and Skill Development, pp. 161-170.

Marshall, V. \& Rossman, S. A. (2016). The Oxford Handbook of Participation in Organizations. Oxford University Press.

Murugesan, R. (2012). Attributes of Leadership for Success in Project Management. International Journal of Engineering and Management Science, 3(3), 326-335.

Northouse, P. G. (2016). Leadership: Theory and practice (7th edition). Thousand Oaks, California, USA, Sage Publications.

Ojokuku, R. M., Odetayo, T. A., \& Sajuyigbe, A. S. (2014). Impact of leadership style on organizational performance: A case study of Nigerian Banks. American Journal of Business and Management, 1(4), $202-207$.

Pedraja-Rejas, L., Rodríguez-ponce, E., \& Rodríguez-Ponze. (2013). Leadership Styles and Effectiveness: a Study of Small Firms in Chile. Interciencia , 31, 500-504.

Pimpa, N., \& Moore, T. (2012). Leadership Styles: A Study of Australian and Thai Public Sectors,. Asian Academy of Management Journal, 17( 2), 21-37.

Shin, A. J., \& Zhou, J. (2013). Transformational leadership, conservation and creativity: Evidence from Korea. Academy of Management Journal, 46, 703-714.

Spreier, S., Fontaine, M., \& Malloy, R. (2016). Leadership Run Amok: The Destructive Potential of Overachievers. Retrieved 1023 , 2017, from Harvard Business Review,: https://hbr.org/2006/06/leadership-run-amok-the-destructive-potential-ofoverachievers

Skouw-Rasmussen, N., Kapande, I., Eisler, T., Andersen, A. S., \& Gedremichael, H. H. (2014). The Fate of Coffee in Kenya - An Assessment of Factors Influencing the Small-Scale Producers Decision-Making Process in Gatugi, Village, Othaya, 4-7

Timmerman, M. (2012). How Participative Leadership Powers a Culture of Productivity. Axiom Consulting Partners, pp 55-58.

Yen, P. H. (2016). Challenges of shifting to task-based language teaching. A story from a Vietnamese Teacher. Can Thuo University Journal of Science. Vol 2, 37-45.

Yukl, G. (2015). Leadership in organizations (7th ed.). Upper Saddle Rive, NJ: Prentice-Hall. 